\title{
PELATIHAN MANAJEMEN PENGELOLAAN DISTRIBUSI PENJUALAN AKSESORIS HANDPHONE PADA PT CHANDY MANDIRI
}

\author{
Nuraini Nuraini ${ }^{1}$, Rais Dera Pua Rawi ${ }^{2}$, Helmi Suaidy ${ }^{3}$, Ramli Lewenussa ${ }^{4}$ \\ ${ }^{1,2,3,4}$ Program Studi Manajemen, Universitas Muhammdiyah Sorong \\ Email: raisdera207@gmail.com
}

\begin{abstract}
Abstrak
Teknologi mungkin tidak asing lagi bagi semua orang, seiring dengan perkembangan zaman, teknologi akan semakin canggih, salah satunya handphone. Handphone mulanya hanya sebagai alat komunikasi jarak jauh, tapi kini fungsi handphone semakin beragam. Handphonepun kini menjadi trend, tidak hanya orang tua saja yang mempunyai handphone, remaja bahkan anak-anak pun kini sudah memiliki handphone.Tujuan dari pelatihan ini adalah untuk mengetahui bagaimana proses manajemen pengelolaan distribusi penjualan dan aksesoris handphone pada PT.Chandy Mandiri kota Sorong. Metode pelaksanaan dilakukan dengan mensosialisasikan bagaimana cara manajemen pengelolaan distribusi penjualan dan aksesoris handphone yang dilakukan pada PT.Chandy Mandiri.Adapun metode yang digunakan dalam kegiatan ini adalah dengan menggunakan metode ceramah, demonstrasi,dan wawancara. Hasil dari pelaksanaan menunjukkan bahwa perlu ada tahap tahap dalam manajemen penjualan meliputi, Prospecting; Perencanaan pra penjualan; Presentasi penjualan; Mengatasi keberatan prospek dan Menutup penjualan, selain itu perlu ada prosedur standar operasional dan manajemen keuangan ketenagaan penjualan dan accesories HP. Hal ini dikarenakan agar segala aktifitas dalam proses jual beli barang dapat sesuai dengan standar yang ditentukan dan dapat menghindari penyalahgunaan barang.
\end{abstract}

Kata Kunci : Manajemen, Pengelolaan Penjualan, Aksesoris

\section{PENDAHULUAN}

Teknologi ini mungkin tidak asing lagi bagi semua orang, seiring dengan perkembangan zaman, teknologi akan semakin canggih. Salah satunya handphone. Handphone mulanya hanya sebagai alat komunikasi jarak jauh, tapi kini fungsi handphone semakin beragam. Handphonepun kini menjadi trend, tidak hanya orang tua saja yang mempunyai handphone, remaja bahkan anak-anak pun kini sudah memili handphone.

Beberapa tahun yang lalu handphone hanya dimiliki oleh para pebisnis yang memang membutuh itu untuk kelancaran pekerjaannya. Seiring berjalannya waktu,handphone bisa dimiliki oleh semua kalangan, karena handphone di lengkapi dengan beberapa fitur yang membuat handphone memiliki fungsi selain menelepon atau saling berkirim pesan singkat. Handphone kini bukan lagi alat untuk komunikasi, namun handphone juga sebagai gaya hidup, penampilan, trend, prestise. Oleh karena itu Tjiptono (2004).Menyatakan 
Perkembangan teknologi dunia yang sangat pesat saat ini, menyebabkan semua perusahaan harus berpikir lebih keras untuk menciptakan produk yang unggul dengan menerapkan strategi-strategi pemasaran. Bauran Pemasaran merupakan salah satu strategi pemasaran untuk meningkatkan jumlah penjualan sebuah produk. Seiring dengan perkembangan zaman, kini orientasi berpikir perusahaan tidak saja pada penciptaan produk unggul, namun bagaimana kepuasan konsumen menjadi tujuan utama. Suaidy (2017) menjelaskan bahwa perkembangan sektor perdagangan khususnya di kota sorong memicu pertumbuhan ekonomi di kawasan tersebut, hal ini memacu perusahaan untuk mengembangkan produk unggulan.

Di samping harga yang di tawarkan cukup terjangkau, berbagai fitur handphone di berikan sebagai penunjang majunya teknologi, perangkat handphone semakin lengkap mulai dari game, MP3, kamera, radio, dan koneksi internet. Di kalangan remaja handphone di gunakan sebagai alat multi fungsi karena multi fungsi tersebut para remaja menggunakan secara positif dan negatif tergantung para individu.

Contoh positif dari penggunaan handphone oleh remaja :

a. Mempermudah komunikasi untuk menyambung silaturahmi (pesan dan telepon)

b. Sarana untuk mencari kebutuhan informasi (internet)

c. Membantu proses pembelajaran.

d. Sarana untuk hiburan (permainan, audio, video)

Contoh negatif dari penggunaan handphone oleh remaja:

a. sebagai sarana untuk menyimpan hal-hal yang mengandung asusila

b. sebagai saranan untuk saling berlomba-lomba menunjukan prestise.

c. Penggunaan tidak sesuai dengan konsisi, Misalnya bermain handphone saat proses belajar sedang berlangsung.

Adapun tujuan dari pelatihan ini adalah untuk mengetahui bagaimana proses pelatihan manajemen pengelolaan distribusi penjualan dan aksesoris handphone pada PT.Chandy Mandiri kota sorong.

\section{METODE PELAKSANAAN}

Pelaksanaan kegiatan ini dilakukan pada PT.Chandy Mandiri (Pink Sellular),Alamat Jalan Ahmad Yaninomor 3D(depan polres).Waktukegiataninidilaksanakanselamaselama3hari dengan maksud kegiatan adalah mensosialisasikan bagaimana caramanajemen pengelolaan distribusipenjualan dan aksesoris handphone yang dilakukan pada PT. Chandy 
Mandiri.Adapun metode yang digunakan dalam kegiatan ini menggunakan metode ceramah, demonstrasi,dan wawancara.

\section{PEMBAHASAN}

Pelaksanaan penelitian ini dilakukan di Pink sellular yang merupakan entitas anak dari PT.Chandy Mandiri, perusahaan ini merupakan kegiatan usaha yang meliputi distribusi dan perdagangan ritel peralatan telekomunikasi seperti telepon seluler,voucher isi ulang, dan berbagaimacam aksesoris handphone.Sesuai dengan visinya, Pink Sellular menyediakan perangkat bergerak (mobile product) dan solusi untuk meningkatkan gaya hidup serta misinya yaitu menjadi perusahaan terdepan di bidang distribusi yang menyediakan rangkaian lengkap perangkat bergerak (mobile product) dan solusi.Pink sellular berhasil menjadi mitra strategi beberapa merek global, seperti apple, Samsung, Huawei, Nokia, Oppo,Vivo, Xiomi, Coolpad dan Mizu, selain itu, Pink Sellular juga memiliki produk sendiri yaitu Politron. Pink Sellular juga melakukan kerja sama strategis dengan operator jaringan selullar untuk mendistribusikan produk mereka, yaitu Telkomsel dan Indosat. Kotler (2009) menjelaskan Saluran distribusi merupakan sekelompok organisasi yang saling bergantung dan terlibat dalam proses pembuatan produk atau jasa yang disediakan untuk digunakan atau dikonsumsi.

Pada tahun 2007 Pink Sellular melakukan perjanjian kerja sama dengan PT.Indosat Tbk (indosat) untuk mendistribusikan produk-produk indosat sebagai agen utama melalui saluran distribusi milik MMS pada daerah tertentu yang di tentukan oleh indosat. Perjanjian itu sudah di perbaharui beberapa kali terakhir pada tahun 2010, dimana perjanjian tersebut di perpanjang menjadi periode 3 (tiga) tahun dari thun 2010 sampai tahun 2013.Cabang PT.Chandi Mandiri yaitu Pink Sellular tebagi di berbagai tempat di kota Sorong. Seperti di JL.Basuki Rahmat kompleks pink no.3D Remu Utara Sorong (samping terminal, depan Gereja Maranatha), JL.Basuki Rahmat No.3D Remu Selata Sorong (Depan Polres), Ruko PD Irian Bhakti No.14 JL.DR.Samratulangi Kampung Baru Sorong, Pasar Sentral, Stand Yohan Supermarket JL.Ahmad Yani Klademak II B Sorong, Stand Mega Mall JL.Basuki Rahmat $\mathrm{Km} .8,5$.

Suatu perusahaan yang berorientasi keuntungan dalam penyelenggaraannya pastilah mempunyai suatu sasaran pemasaran atau target pemasaran dan penjualan serta untuk mencapai target pemasaran dan penjualan tersebut, maka perusahaan memiliki saluran distribusi sesuai dengan perusahaan. Peran sebagai pusat gadget dan aksesoris tentunya 
memberikan pengaruh yang sangat besar bagi outlet kecil yang ada di daerah sorong. Dimana Pink Sellular Masuk dalam kategori Konter terbesar di kota Sorong. Menurut Swastha (2008 :349), Promosi adalah arus informasi atau persuasi satu arah yang dibuat untuk mengarahkan seseorang atau organisasi kepada tindakan yang menciptakan pertukaran dalam pemasaran.

Kantor PT.Chandy Mandiri (Pink Sellular) merupakan lokasi yang sangat strategis dan berada di pusat kota Sorong. Bangunan ruko terdapat 3 lantai, pertama terdiri dari toko penjualan aksesoris, dimana sistem penjualannya secara grosir dan eceran, di bagian belakang terdapat kamar mandi, gudang, dan tempat packing barang. . Lantai 2 terdiri dari ruang meeting yg juga merupakan ruang bussiness manager, supervisior, ruangan admin, ruangan Owner, tempat pembukuan, tempat pemeriksaan jurnal kas, dan tempat penyedia kebutuhan kantor ataupun konter. Selain itu, pada proses transaksi jual beli ada beberapa tahap-tahap dalam manajemen penjualan meliputi: (1) Prospecting; (2) Perencanaan pra penjualan; (3) Presentasi penjualan; (4) Mengatasi keberatan prospek; (5) Menutup penjualan. Kelima tahapan tersebut harus dilaksanakan dengan baik oleh pegawai yang ada, guna untuk menjaga profesionalisme kerja yang baik.

Adapun Jenis dan bentuk penjualan yang diterapkan di Pink Sellular seperti Technical selling, Penjualan tunai, Penjualan secara grosir. Faktor-Faktor yang menghambat dalam pelaksanaandalam Unit Penjualan\& Acesories HP meliputi:

1. Kuranglengkapnya barang yang tersedia di konter,Misalnya: pelindung atau aksesoris handphone harus berbagai macam model, sesuai dengan trend masa kini. Apalagi aksesoris untuk hp yg lagi naik daun seperti Samsung, Oppo, danVivo, stoknya harus di sediakan lebih, agar menambah ketertarikan konsumen untuk membeli produk tersebut.

2. Komplain tentang HPgaransi, Misalnya: pelanggan baru beli hp 1 minggu, tiba-tiba hp nya tidak mau menyala walaupun sudah di cas selama 1 malam, biasannya dari pihak pink sellular menyarankan garansi, tapi terkadang ada beberapa pelanggan yang meminta langsung di gantikan dengan yang baru. Nah di sini butuh peran kepala toko untuk menangulangi masalah yang seperti ini, biasanya kepala toko mengambil jalan tengan, dimana kepala toko memberikan pernyataan bahwa hpnya harus di kirim ke pihak servis center untuk memastikan hpnya masuk kategori garansi atau di sebabkan oleh kesalahan pemakai, waktu yang di berikan kurang lebih 2 minggu, "kalau hpnya masuk kategori garansi pink sellular siap menggantikan dengan unit baru, tp jika dari pihak service center menyatakan bahwa hp nya gugur garansi, otomatis pelanggan harus menunggu sampai proses perbaikannya selesai, waktunya kurang lebih sekitar 2 sampai 3 bulan. 
3. Keterlambatan pengantaran barang, Misalnya: di saat pink selullar kekurangan stok warna handphone yang siap di konter, sementara ada pelanggan yang berminat dengan barang tersebut biasanya pink sellular melakukan pemesanan barang sama pihak gudang, terkadang ada pelanggan yang mau bersabar menunggu, ada yang pergi, ada pula pelanggan yang memilih model lain karena tidak sabar menunggu

Kurangnya penguasaan tentang produk yang di jual, Misalnya: umunya pelanggan yang datang ke pink sellular tujuanya untuk berbelanja hp ataupun aksesoris $\mathrm{hp}$, tentu pelanggan ingin tahu speksifikasi atau kegunaan dari barang yang dia beli, nah biasanya peran SPG sangatlah penting, dimana para pegawai SPG di pink selullar harus mampu menjelaskan apa yang pelanggan tanyakan, dan harus mampu membangun komunikasi dengan pelanggan supaya pelanggan merasa nyaman dan puas untuk berbelanja, sejalan dengan pernyataan Rawi (2017) dan Lewenussa (2017) memaparkan bahwa kinerja pegawai merupakan hal yang sangat penting dalam suatu instansi dan atau perusahaan dalam menjalankan standar prosedur yang berlaku, sehingga dapat mengoptimalkan performance pegawai tersebut.

\section{Prosedur Standar Operasional Penjualan \& Acesories HP}

Pada proses kerja yang berlaku di pink sellular misalnya barang masuk di cek sampai proses penjualannya, Mulai barang itu masuk ke konter, lansung kita mencatat barang tersebut untuk di order dan sebelum pengantaran barang tersebut kita harus meminta persetujuan dari admin, setelah itu kita laporkan ke manajer terebih dahulu dan pihak konter harus meminta tanda tangan pengantar dan si penerima barang tersebut. Selanjutnya barang tersebut keluar dari gudang, pihak gudang harus ada tanda tangan si pembuat dan mengetahui orang yang antar barang dan orang yang menerima barang tersebut. Selain itu, supervisor/asisten yang menerima barang tersebut harus mengecek atau mengetahui semua kondisi barang tersebut apakah sesuai dengan catatan barang atau fisik barangnya seperti,nomor seri hp, warna hp, harga hp,tipe hp. Semua itu harus dicocokkan sesuai dengan barang yang ada. Selanjutnya barang itu dinyatakan cocok, maka akan di buat surat jalan namun jika barangnya tidak cocok maka surat jalan tersebut akan dikembalikan dengan barang tersebut.Hal ini sesuai dengan pernyataan Wangsi dan Rawi (2018), Suaidy (2014) menyatakan bahwa perlindungan terhadap konsumen perlu diterapkan dalam pelaksanaan Ekonomi, guna melindungi setiap konsumen, juga untuk memberikan rasa tanggung jawab kepada para pengusaha dalam setiap kegiatan produksi sehingga tercapai keadilan ekonomi dalam setiap kegiatan pemenuhan kebutuhan (barang dan jasa).Pernyataan Chopra dan Meindl (2001) juga 
memaparkan bahwa manajemen pengelolaan sebuah perusahaan perlu dilaksanakan dengan strategi yang baik, guna meningkatkan laba dan keuntungan sebuah perusahaan.

\section{Manajemen Ketenagaan Penjualan dan Acesories HP}

Supervisor (SPV) adalah pekerja yang berhubungan langsung dengan manajer, namun dalam konteks tanggung jawab, Supervisormempunyai tugas yang tidak mudah. Dalam banyak kasus, Supervisor memiliki tugas yang sangat strategis karena langsung terjun di lapangan melaksanakan semua rencana yang telah di tetapkan manajer.Supervisor memiliki kedudukan istimewa di dalam perusahaan, karena supervisor mempunyai peran penting dalam menjaga hubungan antara Supervisordengan manager, Supervisor dengan staf, dan manajer dengan staf. Hal ini perlu dikarenakan agar setiap pegawai yang ada mampu mengetahui letak, posisi dari pegawainya, juga mampu memberikan kenyaman kerja bagi para pegawai yang ada.

\section{SIMPULAN}

Berdasarkan hasil pelaksanaan yang telah dilaksanakan menunjukkan bahwa sebuah instansi, perusahaan dan lembaga lainnya memerlukan sebuah standar operasional yang jelas, guna untuk mendukung keterlaksanaan mekanisme proses pemasaran dan penjualan. Selain itu pelaksanaan dari setiap tahapan pengelolaan distribusi harus sesuai dengan aturan yang berlaku, agar konsumen merasa puas terhadap pelayanan pelaku usaha.

\section{DAFTAR PUSTAKA}

Chopra, Sunil and Meindl, Peter. (2001). Supply Chain Management: Strategy, Planning and Operating. Prentice-hall

Kotler dan Armstrong. 2000. Dasar-dasar Pemasaran. Prenhallindo: Jakarta.

Lewenussa, R. (2017). Pengaruh Kinerja Operasional Dan Kebijakan Keuangan Terhadap Kinerja Keuanganserta Nilai Perusahaan Di Pt. West Irian Fishing Industries Sorong Papua Barat. JURNAL NOKEN: Ilmu-Ilmu Sosial, 2(2), 68-80.

Rawi, R. D. P. (2017). Analisis Hubungan Motivasi Terhadap Kinerja Pegawai (Studi Kasus Pada Kantor Kecamatan Ruing Kabupaten Ngada NTT). JURNAL NOKEN: IlmuIlmu Sosial, 2(2), 15-28.

Swastha, Basu, D.H., (2008). Manajemen Pemasaran Modern. Liberty: Yogyakarta.

Suaidy, H. Analisa Faktor-Faktor Yang Mempengaruhi Loyalitas Konsumen Pada Rumah Makan Ikan Bakar Mangli.

Suaidy, H. (2017). Analisis Pertumbuhan Ekonomi Wilayah Kota Sorong Tahun 2013-2016. JURNAL NOKEN: Ilmu-Ilmu Sosial, 2(2), 81-89.

Tjiptono, Fandy. (2004). Pemasaran Jasa. Bayu Media: Malang.

Wangsi, M. M., \&Rawi, R. D. P. (2018). Perlindungan Konsumen Dalam Pelabelan Produk Menurut Ekonomi Islam. Sentralisasi, 7(1), 1-9. 